\title{
Evaluation of Adequacy Fishery Port Infrastructure (Case Study on Fishery Port Mimbo Situbondo)
}

\author{
Noor Salim \\ Faculty of Technic, Muhammadiyah University of Jember
}

\begin{abstract}
Fishery Port City Beach is located in the district of Situbondo Banyu Putih which is approximately $50 \mathrm{~km}$ from the city center. Exact location of the fishery port in the district directly adjacent to the Banyu PutihBanyuwangi industrial plant which contained fish canning factory in the district Muncar.In development ,thisport functions not only as a fishery port but also, as the crossing place to theSepudi island which is included of Madura district. Different from the original plan, transportation within the port has changed. Reserved parking area no longer function optimally. So that needs to be addressed and the need for further study are: to analyze the adequacy of the pier and parking lot, and to evaluate the adequacy of the road in the hinterland. From the results, we get few things: The need for the loading dock and mooring for a boat the size of the existing less or more than 10 GT still be fulfilled properly. Unloading dock for ship size is less or more than 10 GT still be met but overload jetty mooring for vessels up to $254 \%$ for vessel with size of more than 10 GT and $128 \%$ for vessels less than 10 GT size. By changing the way the mooring of vessels dilated / transverse require less space, so the ship mooring space requirements can be fulfilled until 2016. The adequacy of existing parking space is available for cars and trucks only and can provide for parking requirement. The number of vehicles entering the port increased so that parking spaces be overloaded so it is need to provide parking spaces for motorcycles and pick-up. By utilizing the tip of the breakwater area for motorcycle parking space $\left(688 \mathrm{~m}^{2}\right)$ with a pattern of two sides and the base of the breakwater area for car parking $\left(650 \mathrm{~m}^{2}\right)$ with a pattern of one side and a parking area that has been available previously for the truck and pick-up, parking space requirements can be fulfilled. Adequacy Road at Hinterland area with increasing number of vehicles in 2016, so the level of service drops to $C$ but still decent. By widening the ring road towards Situbondo according to standard $(7 \mathrm{~m})$, it can be an alternative for heavy vehicles which go to Situbondo.
\end{abstract}

Keywords: Adequacy evaluations, docks, parking, street

\section{Introduction}

Geographically, Situbondo City Region is located directly adjacent to the east side of the ocean that is the Madura Strait, therefore the majority of the population domiciled and do their activity near the beach or coastal region in addition to the City of Situbondo.

Fishery Port City Beach is located in the district of Situbondo Banyu Putih which is approximately 50 $\mathrm{km}$ from the city center. Exact location of the fishery port in the district the Banyu Putih directly adjacent to Banyuwangi industrial plant which contained fish canning factory in the district Muncar.

In the development of this port functions not only as a fishery port but also as the place crossing to the Sepudiisland which is included of Madura district. Different from the original plan, transportation within the port has changed. Reserved parking area no longer function optimally. The visitors who came to trade prefer to park their vehicle not far from where they were. So if they take place in or on the side of the breakwater pier, they park their vehicles there as well as the location because distance of the parking area and a desirable place is too far.

Fishery port in carrying out various activities should be equipped with the dock, which is consist of unloading dock, mooring docks, and dock supplies. These facilities must have to support each other so that it will launch all activities that occur in the fishery port.

Under the circumstances, there are several problems need attention and need to be further investigated, namely: to analyze the adequacy of the pier and parking lot, and to evaluate the adequacy of the road in the hinterland area.

\section{Research Methodology}

Operational scheme of research conducted to assess the transportation management of fishing ports are presented in the following chart. 


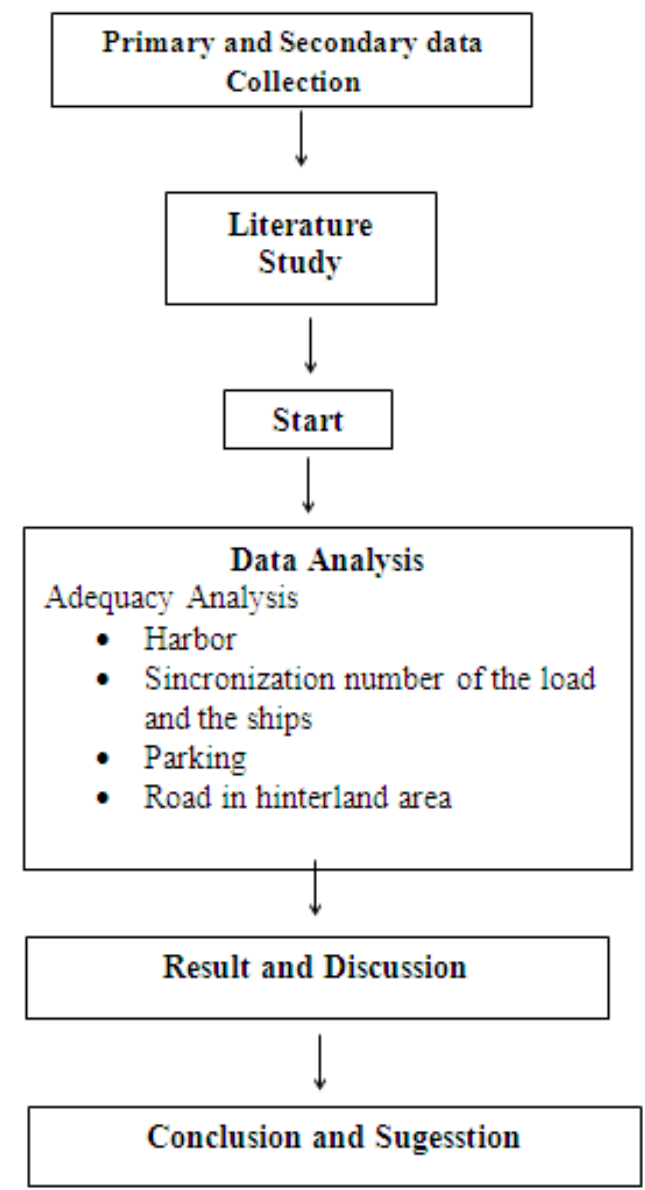

Figure 1. Framework of Operational Research

\section{Research Location}

The research was conducted in coastal fisheries the Port City of Situbondo and in the hinterland traffic, in this intersection a four-stroke without signal as sample.

\section{Secondary Data}

Secondary data include:

1. Ships trends data, obtained from Fishery Port Manager Unit of Mimbo Beach.

2. Vehicles trends data, obtained from the Central Statistics Agency of Situbondo City.

\section{Primary Data}

Primary data were obtained by direct observation include:

1. The number of vehicles in and out of the port data

2. Traffic volume at the intersection of four junction in hinterland area data

\section{Data Collection}

In addition to the secondary data obtained from the SitubondoFishery PortBeach Manager Unit, Situbondo Statistics Center, and the data from the department of marine and coastal fishing town of Situbondo, conducted a survey to obtain primary data on the number of vehicles in and out of the port and the characteristics of traffic in hinterland area. In the survey, there are several qualifications to the data collection process which can be seen in the following table.

Table 1. Qualification data collection process

\begin{tabular}{|l|l|l|l|}
\hline Number & Qualifications & Exit-entry fishery port & Not signalized intersection of four \\
\hline 1 & $\begin{array}{l}\text { Surveyor which } \\
\text { involved in the } \\
\text { survey }\end{array}$ & $\begin{array}{l}\text { Surveyor involved in the survey required } \\
\text { is 4 people. Each observed a vehicle } \\
\text { coming out of the harbor and the } \\
\text { entrance to the harbor. }\end{array}$ & $\begin{array}{l}\text { Surveyor required is 4 people. Each } \\
\text { observing one segment intersection of } \\
\text { four intersection. }\end{array}$ \\
\hline 2 & Technical survey & $\begin{array}{l}\text { Survey conducted by recording the type } \\
\text { and number of vehicles that enter or exit }\end{array}$ & $\begin{array}{l}\text { The survey was conducted by recording } \\
\text { the type and number of passing vehicles }\end{array}$ \\
\hline
\end{tabular}




\begin{tabular}{|l|l|l|l|}
\hline & & from the harbor. & $\begin{array}{l}\text { in each segment of the intersection of } \\
\text { four. }\end{array}$ \\
\hline 3 & $\begin{array}{l}\text { The timing of the } \\
\text { survey }\end{array}$ & $\begin{array}{l}\text { The survey was held on Sunday, June 16, } \\
2013 \text { at 06:00 to 8:00 pm and at 15:00 to } \\
17: 00 \mathrm{pm} .\end{array}$ & $\begin{array}{l}\text { Surveys were conducted on Monday, } \\
\text { June 17th, 2013 at 7:00 to 9:00 pm. }\end{array}$ \\
\hline 4 & $\begin{array}{l}\text { Working Equipment } \\
\text { used }\end{array}$ & $\begin{array}{l}\text { Surveyform, used to record the data of } \\
\text { the survey include the type of vehicle, } \\
\text { time and number of vehicles. }\end{array}$ & $\begin{array}{l}\text { Survey form, is used to record the data } \\
\text { of the survey include the type of vehicle, } \\
\text { time and number of vehicles. }\end{array}$ \\
\hline
\end{tabular}

\section{Processing and Data Analysis}

From the collection of primary and secondary data then they were analyzed. All of this analysis is to determine some characteristics which must be fulfilled at this time and for a period of 5 (five) years later. The things to be analyzed is as follows.

- Number of Ships

- Number of vehicles in and out of the harbor

- Dock Infrastructure

- Parking Infrastructure

- Road Infrastructure in the Hinterland area

\section{Ship volume}

\section{Research Analysis Results And Discussion}

The volume of the shipwhich is the number of ships mooring every month for one year in 2012 either licensed or unlicensed presented in the following table.

Table 2. The volume of the port in 2012

\begin{tabular}{|l|l|l|l|}
\hline NUMBER & MONTH & VOLUME (UNIT) & PERCENTAGE \\
\hline 1 & January & & $8,03 \%$ \\
\hline 2 & February & 163 & $6,40 \%$ \\
\hline 3 & March & 180 & $7,08 \%$ \\
\hline 4 & April & 189 & $7,44 \%$ \\
\hline 5 & May & 191 & $7,51 \%$ \\
\hline 6 & June & 194 & $7,63 \%$ \\
\hline 7 & July & 203 & $7,99 \%$ \\
\hline 8 & August & 206 & $8,11 \%$ \\
\hline 9 & September & 228 & $8,95 \%$ \\
\hline 11 & October & 243 & $9,54 \%$ \\
\hline 12 & November & 253 & $9,94 \%$ \\
\hline & Desember & 289 & $11,37 \%$ \\
\hline
\end{tabular}

Source: Results of Analysis

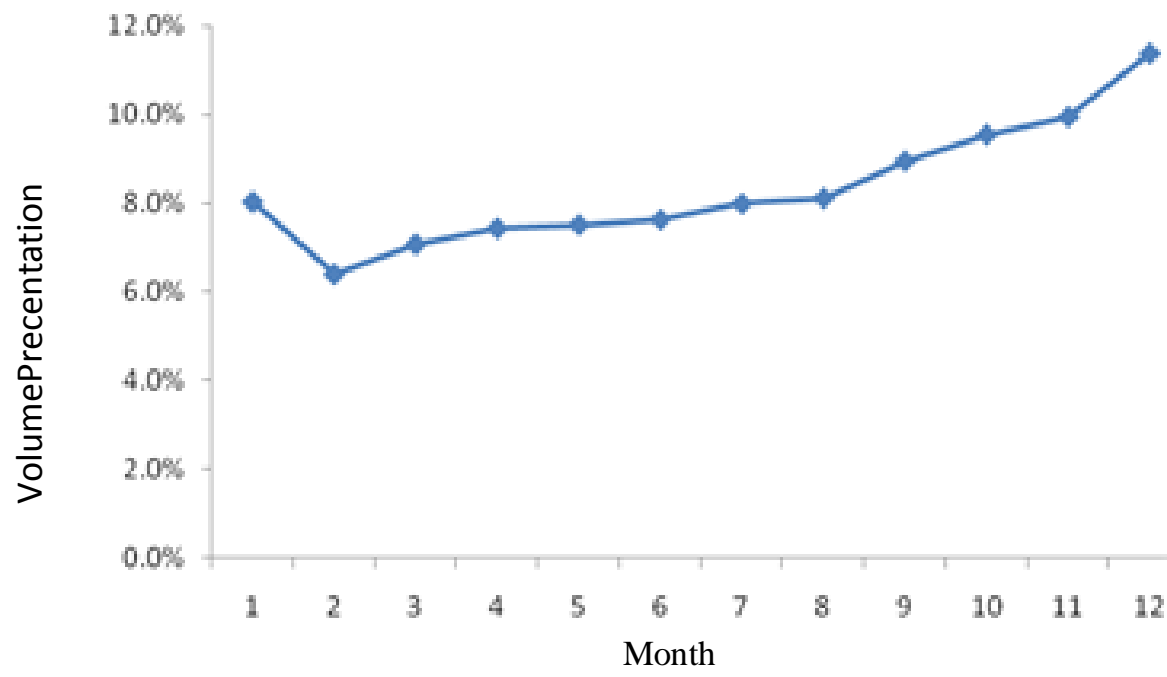

Figure 2. Graph the volume percentage of the vessel in 2012

Trends in the number of ships in the fishing port each year is different, because affected by fishing season. Based on the above chart, it can be seen that the volume of the vessel in 2012 was highest in December 
that is $11.37 \%$ number of 289 ships of various sizes. The maximum of the next data to be sampled as the basis for calculating the adequacy of the pier. Here is a daily volume licensed ship in December 2012 based on the size of the vessel:

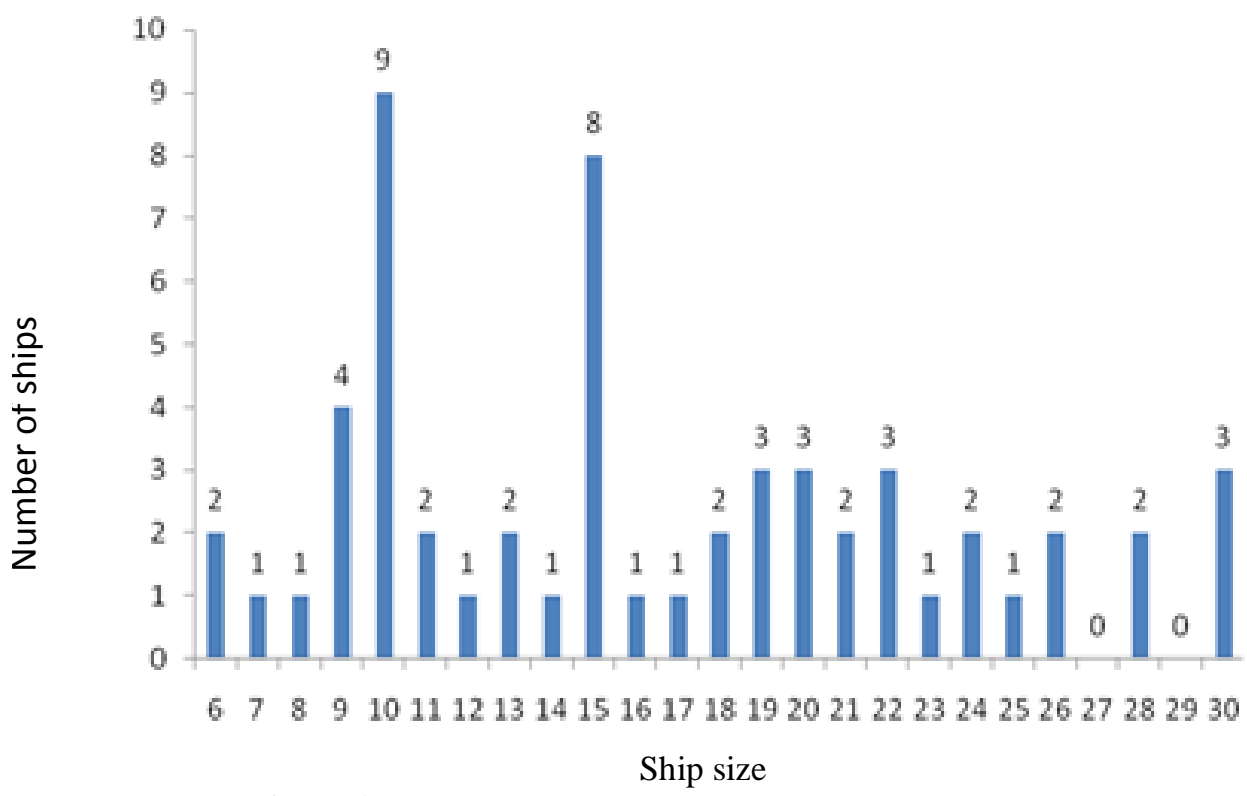

Figure 3. Graph the maximum number of mooring ships in 1 day

Based on the Minister of Marine and Fisheries Decree No. 165 In 2000, one of the criteria for Fishery Harbor Beach is the anchor mooring facilities for fishing boats with at least $10 \mathrm{GT}$.

From the data above, obtained maximum number of vessels in one day was 57 vessels, or $24.46 \%$ of the total number of ships for a month. For the size of the largest ships that dock is a $10 \mathrm{GT}$ with the maximum number of ships mooring in one day was 9 ships or some $15.79 \%$. While the vessel is less than 10 GT number 8 vessels or $14.04 \%$ and more than or equal to 10 GT number 49 ships or $85.96 \%$.

\section{Adequacy of Dock}

Based on the Minister of Marine and Fisheries Decree No. 165 In 2000, the port has a quay length of coastal fisheries at least 100 meters and can accommodate at least 30 boats or $300 \mathrm{GT}$ at one time.

Coastal fishing port Situbondo City has dock, that is landing dock / unloading and mooring docks which are differentiated according to the size of the ship. The effective length of each pier can be seen in the table below:

Long landing dock / unloading required for today can be seen from the following calculation:

The landing dock / loading for vessel size> $30 \mathrm{GT}$

loading and unloading time $\quad: 2$ hours

port operational time $\quad: 24$ hours

then the value $\mathrm{y} \quad: 12$ hours

size vessels $10 \mathrm{GT}$, LOA : $17.6 \mathrm{~m}$

number of vessels anchored $\quad: 100$ ships

$\operatorname{Ld}=\frac{100}{12} 17,6+0,15(17,6): 168.67 \mathrm{~m} \approx 168 \mathrm{~m}$

$$
\mathbf{L d}=\frac{\mathbf{N}}{\gamma} \mathbf{L}+\mathbf{0 , 1 5} \mathbf{L}
$$

So the landing dock needed for today is $168 \mathrm{~m}$. It can be used for \pm 3 vessels simultaneously with the space between the freedom of the ship is $0.15 \mathrm{~L}=2,64 \mathrm{~m}$. From the above calculation it can be seen that the length of the pier that available is sufficient for current needs. The length of the pier is used along $168 \mathrm{~m}$ of quay length of $200 \mathrm{~m}$ that provided.

From the analysis of the adequacy of the dock, then by changing the way the mooring of vessels dilated / transverse require less space so the ship mooring space requirements can be fulfilled until 2016. Transportation management at the dock that is needed is revamping the layout, repair ships queuing system. 
Adequacy of parking space

Analysis of Existing Parking Space

The total effective area available parking area is $3402.88 \mathrm{~m}^{2}$. The area of $1458.38 \mathrm{~m}^{2}$ of which is a parking area for cars and other $1944.5 \mathrm{~m}^{2}$ is truck parking area. While the parking area for pick-ups, motorcycles, and unmotorized vehicles are not available.

In determining the need for parking space with the approach used accumulated the highest amount of accumulated parking. Based parking accumulation that occurred during the investigation in the field, the need for a parking space can be calculated by determining the number of vehicles at the time of maximum parking accumulation. The following is a calculation of existing parking space requirements:
Motor. $284 \times 1.5 \quad: 426 \mathrm{~m} 2$
Car $\quad: 34 \times 12.5 \quad: 425 \mathrm{~m} 2$
Truck: $12 \times 42.5 \quad: 510 \mathrm{~m} 2$
Unmotor : $57 \times 1,5 \quad: 85.5 \mathrm{~m} 2$
Pickup : $60 \times 15: 900 \mathrm{~m} 2$

From the above calculations for a car parking space requirement is $425 \mathrm{~m}^{2}(29.14 \%)$ and a parking space for a truck that is $510 \mathrm{~m}^{2}(26.23 \%)$. It can be seen that the parking spaces are available to provide for parking today.

\section{Parking Space Needs Analysis 5 Year Upcoming}

Predicted increase in the number of vehicles in 2012 - 2016 based on the secondary data obtained from the fisheries harbor Manager cottageMimboare as follows:

$\begin{array}{ll}\text { Motor } & : 4.78 \% \text { per year } \\ \text { Car } & : 5.02 \% \text { per year } \\ \text { Truck } & : 12.50 \% \text { per year }\end{array}$

Pick-up : $12.50 \%$ per year

Calculations predicted number of vehicles parked in the accumulation of 2012 - 2016 can be seen in the following table:

Table 3. Parking accumulation data in 2007-2012

\begin{tabular}{|c|c|c|c|c|c|c|}
\hline \multirow{2}{*}{$\begin{array}{l}\text { VEHICLE } \\
\text { (unit) }\end{array}$} & \multicolumn{6}{|c|}{ YEAR } \\
\hline & 2007 & 2008 & 2009 & 2010 & 2011 & 2012 \\
\hline MOTOR & 233 & 244 & 256 & 269 & 283 & 297 \\
\hline CAR & 27 & 29 & 30 & 32 & 33 & 35 \\
\hline TRUCK & 7 & 8 & 9 & 10 & 11 & 13 \\
\hline PICK-UP & 34 & 39 & 45 & 51 & 58 & 67 \\
\hline
\end{tabular}

Table 4. Predicted parking accumulation in 2011-2016

\begin{tabular}{|c|c|c|c|c|c|c|}
\hline \multirow{2}{*}{$\begin{array}{l}\text { VEHICLE } \\
\text { (unit) }\end{array}$} & \multicolumn{6}{|c|}{ YEAR } \\
\hline & 2011 & 2012 & 2013 & 2014 & 2015 & 2016 \\
\hline MOTOR & 283 & 297 & 312 & 327 & 343 & 359 \\
\hline CAR & 33 & 35 & 37 & 39 & 41 & 43 \\
\hline TRUCK & 11 & 13 & 15 & 17 & 19 & 21 \\
\hline PICK-UP & 58 & 67 & 76 & 86 & 96 & 108 \\
\hline
\end{tabular}

Source: Results of Analysis

Based on the analysis of the parking accumulation predictions 2012 - 2016, the prediction of parking space requirements in 2016 can be calculated by the following calculation:

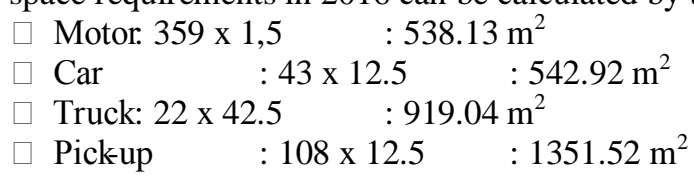

From the above calculation, predicted the need for car parking spaces increased to $538.13 \mathrm{~m}^{2}$ and for the truck is $919.04 \mathrm{~m}^{2}$. The increase in parking space requirements increased by $94.93 \%$. While parking space for pick-up which was not originally provided, in 2016 the number increased to 108 units. This condition requires to provide parking space for pick-up as it may not be left parked in any place considering its function as a transporter of fish.

\section{Alternative of Parking Adequacy \\ 1. Motor cycle}

The majority of visitors who use the port of the motor is intended for tours. Because of parking spaces for motorcycles is not provided, the riders parked their bikes around the fish auction place to their liking. By the 
increasing number of motorcycles in 2016 will further aggravate the situation if a parking space for motor still not provided.

Breakwater is a destination for visitors who aim to travel. Seeing this situation, the best solution is to provide motorcycle parking spaces in the area of the breakwater. The following is the calculation of the adequacy of motorcycle parking spaces if bike parking spaces in the breakwater area is planned:

number of motor : 359 engine

parking space unit of motor $\quad: 0.75 \mathrm{~m} \times 2.00 \mathrm{~m}$

breakwater width $\quad: 7.5 \mathrm{~m}$

long breakwater (motorcycle parking area) : $172 \mathrm{~m}$

If it is planned to use the parking pattern 2 sides, then the length of parking spaces required is:

$$
\begin{aligned}
\frac{359 \times 0,75 \mathrm{~m}}{2} & \leq 172 \mathrm{~m} \times 2 \\
269,25 \mathrm{~m} & \leq 344 \mathrm{~m}
\end{aligned}
$$

From the above calculation it can be seen that the parking spaces are provided to meet the needs of 688 $\mathrm{m}^{2}$ park is $538.5 \mathrm{~m}^{2}$. Here is a plan drawing motorcycle parking spaces:

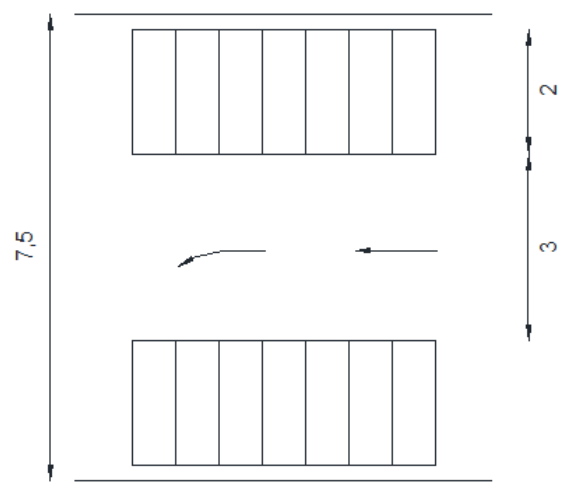

Figure 4. Parking a motor with a pattern of 2 sides

\section{Car}

Same with visitors using motors, majority of visitors who use the car also aims to tour and breakwater is their destination. So for a car parking space should also be provided in the area of the breakwater. The following is the calculation of the adequacy of car parking spaces if the planned car parking spaces in the breakwater area:

number of cars

parking space unit of car $\quad: 2.50 \mathrm{~m} \times 5.00 \mathrm{~m}$

breakwater width $\quad: 7.5 \mathrm{~m}$

long breakwater (car park area) : : $130 \mathrm{~m}$

If it is planned to use the parking one side of the pattern, then the length of parking spaces required is:

$$
\begin{gathered}
43 \times 2,50 \mathrm{~m} \leq 130 \mathrm{~m} \\
108,58 \mathrm{~m} \leq 130 \mathrm{~m}
\end{gathered}
$$

From the above calculation it can be seen that the car parking spaces are provided which can meet the needs of $650 \mathrm{~m}^{2}$ parking is $542.9 \mathrm{~m}^{2}$. Here is a picture of car parking space plan:

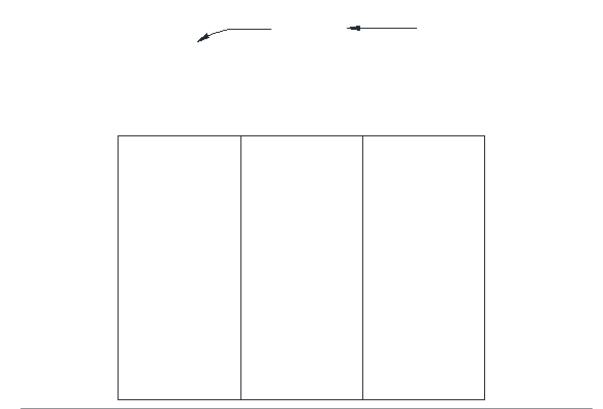

Figure 5. The car park to the pattern of one side 


\section{Truck and Pick Up}

The purpose of the port visitors who use truck and pick up is for transporting fish and distributed to a particular place. Fish taken from public fisherman, must be pass through the fish auction first. However, for certain companies that have their own fishing boats, truck or pick-up can simply take the fish from the boat.

To overcome the problem of truck parking demand and a pick up in 2016, a truck and pick up parking space can be merged because their function is same. The parking spaces should not be far from the place of extraction of fish.

The parking spaces are required for the truck is $919.04 \mathrm{~m}^{2}$ and for the pick up is $1351.52 \mathrm{~m}^{2}$. So, the total requirement is $2270.56 \mathrm{~m}^{2}$. The parking spaces that can be used is the area of the parking space of Fish Auction Place area as wide of $1944.5 \mathrm{~m}^{2}$ and current car parking space area of $1458.38 \mathrm{~m}^{2}$. So, the total area of the parking area is $3402.88 \mathrm{~m}^{2}$.

From the analysis above, available parking spaces area $3402.88 \mathrm{~m}^{2}$ can fulfill the parking needs of truck and pickup that is $2270.56 \mathrm{~m}^{2}$.

For a port visitor who use car and motorcycle aiming to shop, can be directly parked their vehicles in front of the parking area stalls selling that already available.

From the analysis of the adequacy of parking, then by using the tip of the breakwater area for motorcycle parking space $\left(688 \mathrm{~m}^{2}\right)$ with a pattern of two sides and the base of the breakwater area for car parking $\left(650 \mathrm{~m}^{2}\right)$ with a pattern of one side and a parking area that has been available previously for the truck and pick-up, parking space requirements can be met. Transportation parking management required is revamping the layout of the parking of vehicles, repair queuing system, and policies related to the tariff.

\section{Adequacy Analysis on Regional Road Hinterland \\ Road Geometric}

The analyzes were performed at the intersection of four unsignal junction that closest to the port gate. This road has a width of $\pm 5 \mathrm{~m}$ for segment SumberAnyar Village direction, $\pm 10 \mathrm{~m}$ for the segment toward the port, $\pm 7 \mathrm{~m}$ for the segment towards the city and $\pm 10 \mathrm{~m}$ for the segment direction KarangTekok Village. This road is a two lane road and two-way.

\section{Traffic volume}

Traffic volume obtained from the traffic results survey on the same day, which is Monday at 7:00 to 9:00 pm time is assumed to be stable enough to capture the data traffic flow, with a duration about 5 minutes. The survey was conducted in four segments, namely, the direction of the SumberAnyar Village, direction of the harbor, direction of the city, and the direction of the Village of KarangTekok. From the results of this survey obtained the magnitude of the flow of traffic on each segment. So it can be known volume of vehicles involved in each road segment. Here are the results of the vehicular traffic volume calculation :

Table 5. Volume LV (pcu / h)

\begin{tabular}{|l|l|l|l|l|}
\hline \multirow{2}{*}{ Origin } & Destination & \multicolumn{3}{l|}{} \\
\cline { 2 - 5 } & Fishery Port & The City & SumberAnyar Village & KarangTekok Village \\
\hline Fishery Port & 0 & 19 & 5 & 1 \\
\hline The City & 10 & 0 & 19 & 1 \\
\hline SumberAnyar Village & 6 & 16 & 0 & 0 \\
\hline KarangTekok Village & 1 & 2 & 0 & 0 \\
\hline
\end{tabular}

Source: Results of Analysis

Table 6. Volume HV (pcu / h)

\begin{tabular}{|l|l|l|l|l|}
\hline \multirow{2}{*}{ Origin } & Destination & KarangTekok Village \\
\cline { 2 - 5 } & Fishery Port & The City & SumberAnyar Village & Karang \\
\hline Fishery Port & 0,0 & 24,8 & 1,5 & 0,0 \\
\hline The City & 17,3 & 0,0 & 10,5 & 2,3 \\
\hline SumberAnyar Village & 0,0 & 9,0 & 0,0 & 0,8 \\
\hline KarangTekok Village & 0,8 & 1,5 & 0,0 & 0,0 \\
\hline
\end{tabular}

Source: Results of Analysis

Table 7. Volume MC (pcu / h)

\begin{tabular}{|l|l|l|l|l|}
\hline \multirow{2}{*}{ Origin } & Destination & Ke City & SumberAnyar Village & KarangTekok Village \\
\cline { 2 - 5 } & Fishery Port & The & 11,3 \\
\hline Fishery Port & 0,0 & 44,5 & 74,5 & 17,3 \\
\hline The City & 48,5 & 0,0 & 114,3 & 3,5 \\
\hline SumberAnyar Village & 74,5 & 78,5 & 0,0 & 0,0 \\
\hline KarangTekok Village & 9,3 & 8,0 & 5,8 & \\
\hline
\end{tabular}

Source: Results of Analysis 
From the above data, it can be seen $\mathrm{Q}_{\mathrm{TOT}}$ namely:

$\mathrm{Q}_{\mathrm{TOT}}=\mathrm{Q}_{\mathrm{LV}}+\mathrm{Q}_{\mathrm{HV}}+\mathrm{Q}_{\mathrm{MC}}$

$\mathrm{Q}_{\text {Tот }}=80+68.5+490$

$\mathrm{Q}_{\mathrm{TOT}}=638.5 \mathrm{pcu} /$ hour

\section{Capacity and Degree of Saturation}

In determining capacity, necessary steps in accordance with MKJI calculations. Here are the steps in determining the capacity :

1) The value of the base capacity (Co)

This intersection has four arms, each of which has 2 row and 2 lanes. Therefore, according to MKJI 97, this intersections are type 422, so it has Co value $2900 \mathrm{pcu} /$ hour.

2) Approach width adjustment factor $(\mathrm{Fw})$

$\begin{array}{lll}\mathrm{FW} & = & 0.70+0.0866(\mathrm{Wi}) \\ \mathrm{FW} & = & 0.70+0.0866(4) \\ \mathrm{FW} & = & 1.046\end{array}$

3) The adjustment factor is the main street median $\left(F_{M}\right)$

Because there are no medians on main roads, then the value of $F_{M}$ is 1.00 .

4) The adjustmentsize of the city factor $\left(F_{C S}\right)$

Situbondo is a very small town with a population $<0.1$ million, then the $\mathrm{F}_{\mathrm{CS}}$ value was 0.82 .

5) The adjustment type of side barrier road environment and non-motorized vehicles factor

Type of RE road environment class = commercial

Side barriers SF class $\quad=$ low

The ratio of non-motorized vehicles $\mathrm{P}_{\mathrm{UM}} \quad=1.0$

So, $\mathrm{F}_{\mathrm{RSU}} \quad=0.86$

6) Turn left adjustment factor $\left(\mathrm{F}_{\mathrm{LT}}\right)$

$\begin{array}{lll}\mathrm{F}_{\mathrm{LT}} & = & 0.84+1.61\left(\mathrm{P}_{\mathrm{LT}}\right) \\ \mathrm{F}_{\mathrm{LT}} & = & 0.84+1.61(0.25)=1.24\end{array}$

7) Turn Right adjustment factor $\left(\mathrm{F}_{\mathrm{RT}}\right)$

Due to the intersection with four arms, then the value of the $F_{R T}$ is 1.0.

8) Minor road flow adjustment factor $\left(F_{M I}\right)$

$\mathrm{F}_{\mathrm{MI}}=1.19 \times \mathrm{PMI} 2-\mathrm{PMI}+1.19 \times 1.19$

$\mathrm{F}_{\mathrm{MI}}=1.19 \times 0.52$ to $1.19 \times 0.5+1.19$

$\mathrm{F}_{\mathrm{MI}} \quad=\quad 0.297$ to $0.595+1.19$

$\mathrm{F}_{\mathrm{MI}}=0.892$

From the data above, the capacity can be calculated as follows:

$\mathrm{C}=\mathrm{Co} \times \mathrm{F}_{\mathrm{W}} \times \mathrm{F}_{\mathrm{M}} \times \mathrm{F}_{\mathrm{CS}} \times \mathrm{F}_{\mathrm{RSU}} \times \mathrm{F}_{\mathrm{LT}} \times \mathrm{F}_{\mathrm{RT}} \times \mathrm{F}_{\mathrm{MI}}$

$\mathrm{C}=2900 \times 1.046 \times 1.00 \times 0.82 \times 0.86 \times 1.24 \times 1.0 \times 0.892$

$\mathrm{C}=2366.075 \mathrm{pcu} /$ hour

So the degree of saturation (DS) is:

$\mathrm{DS}=\mathrm{Q}_{\mathrm{TOT}} / \mathrm{C}$

$\mathrm{DS}=635 / 2366.075$

$\mathrm{DS}=0.29$

From the analysis above obtained value of DS was 0.29 , which means that the intersection of four levels of service B, namely:

1. Flow is stable with moderate traffic volume and speed began to be restricted by traffic conditions.

2. The traffic density low and internal resistance not affect the speed of traffic.

3. The driver still has enough freedom to choose the speed and lane to use.

Hinterland Regional Traffic Analysis 5 Year Upcoming

- Predicted increase in the number of vehicles in 2016

Based on data from the Central Statistics Agency Situbondo City, obtained number of vehicles in 2007 - 2010 are as follows:

Table 8. The volume of vehicles in Situbondo in 2007-2010 (units)

\begin{tabular}{|l|l|l|l|l|}
\hline Vehicles & $\mathbf{2 0 0 7}$ & $\mathbf{2 0 0 8}$ & $\mathbf{2 0 0 9}$ & $\mathbf{2 0 1 0}$ \\
\hline MC & 43791 & 53149 & 61864 & 64253 \\
\hline LV & 4123 & 5004 & 5825 & 6050 \\
\hline HV & 3759 & 4562 & 5310 & 5515 \\
\hline
\end{tabular}

Source: Results of Analysis 
From the above data, to predict the increase in the number of vehicles in 2016 can use a Line Linear Equations.

\section{MC}

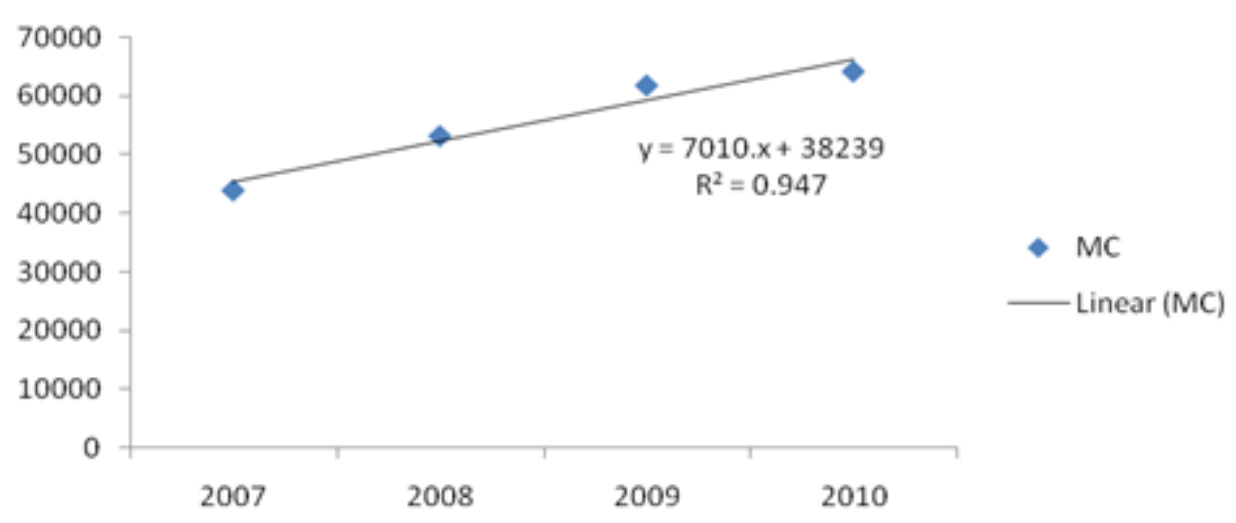

Figure 6. Graph linear equations MC in 2007-2010

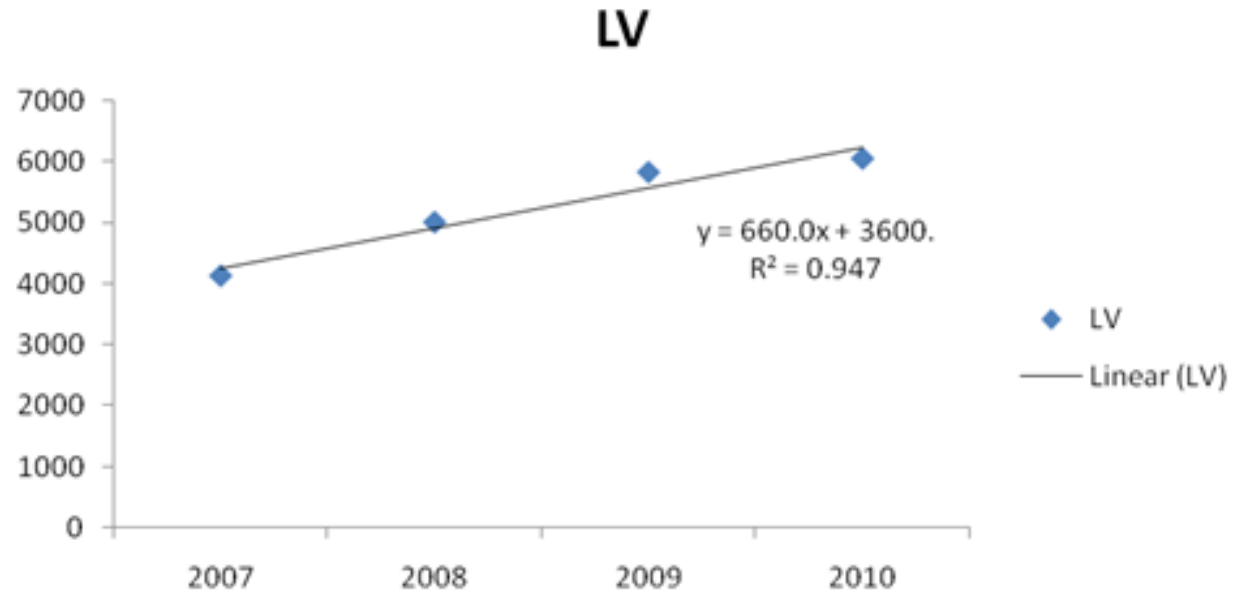

Figure 7. Graph linear equations LV in 2007-2010

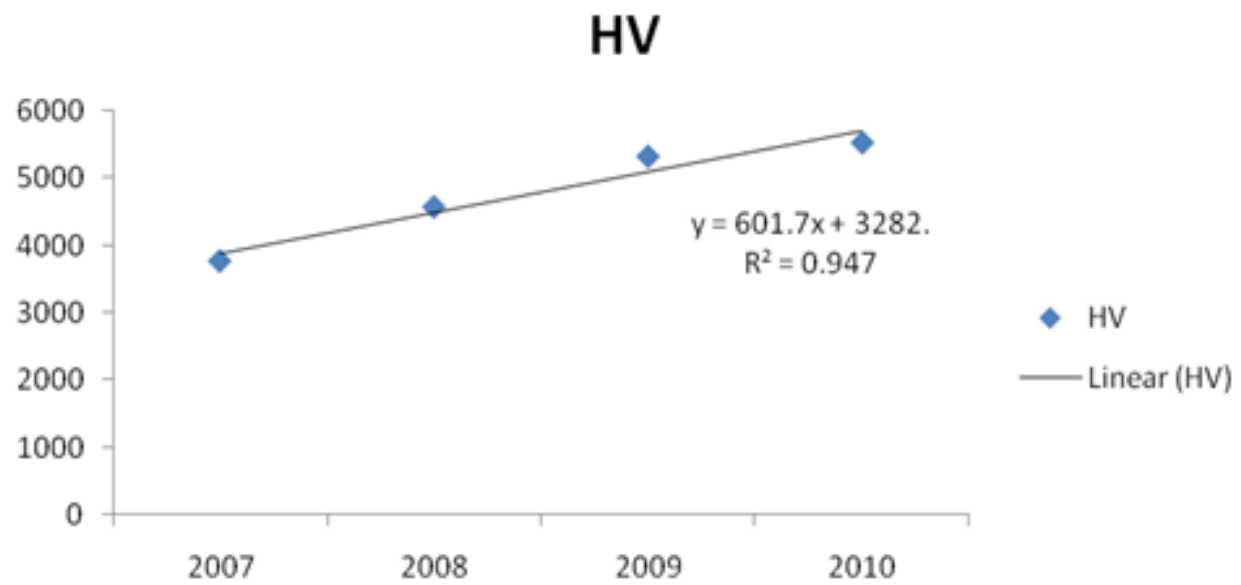

Figure 8. Graph linear equations HV years 2007-2010

From the above linear equation, can be seen the number of vehicles in the year 2011 - 2016 are as follows: 
Table 9. Prediction of volume of vehicles in Situbondo 2016 (units)

\begin{tabular}{|l|l|l|l|l|l|l|}
\hline Vehicles & $\mathbf{2 0 1 1}$ & $\mathbf{2 0 1 2}$ & $\mathbf{2 0 1 3}$ & $\mathbf{2 0 1 4}$ & $\mathbf{2 0 1 5}$ & $\mathbf{2 0 1 6}$ \\
\hline MC & 73289 & 80299 & 87309 & 94319 & 101329 & 108339 \\
\hline LV & 6900 & 7560 & 8220 & 8880 & 9540 & 10200 \\
\hline HV & 6291 & 6892 & 7494 & 8096 & 8697 & 9299 \\
\hline
\end{tabular}

Source: Results of Analysis

From the analysis above it can be seen that the increase in the number of vehicles in Situbondo from year to year, an average of $9.12 \%$. So, the prediction of the number of vehicles per hour in the hinterland in 2016 are as follows:

Table 10. Volume LV 2016 (pcu / h)

\begin{tabular}{|l|l|l|l|l|}
\hline \multirow{2}{*}{ Origin } & Destination & The City & SumberAnyar Village & KarangTekok Village \\
\cline { 2 - 5 } & Fishery Port & 29 & 7 & 2 \\
\hline Fishery Port & 0 & 0 & 29 & 2 \\
\hline The City & 15 & 24 & 0 & 0 \\
\hline SumberAnyar Village & 9 & 2 & 0 & 0 \\
\hline KarangTekok Village & 2 & 0 & \\
\hline
\end{tabular}

Source :Analisys Results

Table 11. Volume of HV 2016 (pcu / h)

\begin{tabular}{|l|l|l|l|l|}
\hline \multirow{2}{*}{ Origin } & Destination & \multicolumn{2}{l|}{} \\
\cline { 2 - 5 } & $\begin{array}{l}\text { Fishery } \\
\text { Port }\end{array}$ & The City & $\begin{array}{l}\text { SumberAnyar } \\
\text { Village }\end{array}$ & $\begin{array}{l}\text { KarangTekok } \\
\text { Village }\end{array}$ \\
\hline Fishery Port & 0,0 & 38,3 & 2,3 & 0,0 \\
\hline The City & 26,7 & 0,0 & 16,2 & 3,5 \\
\hline SumberAnyar Village & 0,0 & 13,9 & 0,0 & 1,2 \\
\hline KarangTekok Village & 1,2 & 2,3 & 0,0 & 0,0 \\
\hline
\end{tabular}

Source: Results of Analysis

Table 12. Volume MC 2016 (pcu / h)

\begin{tabular}{|l|l|l|l|l|}
\hline \multirow{2}{*}{ Origin } & Destination & \multicolumn{2}{|l|}{$\begin{array}{l}\text { KarangTekok } \\
\text { Village }\end{array}$} \\
\cline { 2 - 5 } & Fishery Port & The City & $\begin{array}{l}\text { SumberAnyar } \\
\text { Village }\end{array}$ & 17,4 \\
\hline Fishery Port & 0,0 & 68,8 & 115,3 & 26,7 \\
\hline The City & 75,0 & 0,0 & 176,8 & 5,4 \\
\hline SumberAnyar Village & 115,3 & 121,4 & 0,0 & 0,0 \\
\hline KarangTekok Village & 14,3 & 12,4 & 8,9 & \multicolumn{2}{l}{} \\
\hline
\end{tabular}

Source: Results of Analysis

From the above data, it can be seen $\mathrm{Q}_{\text {Tот }}$ for 2016. They are:

$\begin{array}{lll}\mathrm{Q}_{\text {TOт }} & = & \mathrm{Q}_{\mathrm{LV}}+\mathrm{Q}_{\mathrm{HV}}+\mathrm{Q}_{\mathrm{MC}} \\ \mathrm{Q}_{\text {TOT }}= & 119+106+758 \\ \mathrm{Q}_{\text {TOT }}= & 982 \mathrm{pcu} / \mathrm{hr}\end{array}$

\section{Degree of Saturation (DS)}

The degree of saturation (DS) in 2016 are as follows:

$\mathrm{DS}=\mathrm{Q}_{\mathrm{TOT}} / \mathrm{C}$

$\mathrm{DS}=982 / 2366.075$

$\mathrm{DS}=0.42$

From the analysis above DS value obtained was 0.42 , which means that the intersection of four had a level of service C, namely :

1. Flow is stable but the speed and movement of vehicles controlled by the higher traffic volume.

2. The traffic density was moderate due to the traffic internal resistance increased.

3. The driver has a limitation to select speed, change lanes or precede.

\section{Alternative Traffic Hinterland}

From the analysis of the above study concluded that traffic conditions hinterland today to five years is still feasible. Associated with urban traffic regulations that HV vehicles may not cross the city need an alternative to the HV traffic flow towards Situbondo.

There is a road leading Situbondo port right next to the gate that was originally supplied to the HV vehicles will be out from Situbondo towards Banyuwangi. However, it doesn't work because the width road is 
less than the standard that is $5 \mathrm{~m}$. In order to its function, the way need to be widened. This method is possible because in the right and left of the road there are road shoulder width respectively $\pm 1.5-2 \mathrm{~m}$.

\section{Conclusion}

\section{Conclusions And Recommendations}

Based on the results of research and analysis of data, it can be concluded as follows:

1. Dock Adequacy

a) Needs of existing docks unloading and mooring for boats less size and more than 10T still be fulfilled properly.

b) Unloading dock for ship size is less or more than 10 GT still be met but overload jetty mooring for vessels up to $254 \%$ the size of more than $10 \mathrm{GT}$ and $128 \%$ for vessels less than $10 \mathrm{GT}$ size.

c) By changing the way the mooring of vessels dilated / transverse require less space so the ship mooring space requirements can be fulfilled until 2016.

2. Parking Space Adequacy

a) Existing parking spaces are only available for cars and trucks only and enough for parking needs.

b) The number of vehicles entering the port increased, so that parking spaces be overloaded, so it is needs to provide parking spaces for motorcycles and pick-up.

c) By utilizing tip of the breakwater area for motorcycle parking space $\left(688 \mathrm{~m}^{2}\right)$ with a pattern of two sides and the base of the breakwater area for car parking $\left(650 \mathrm{~m}^{2}\right)$ with a pattern of one side and a parking area that has been available previously for the truck and pick-up, parking space requirements can be met.

3. Adequacy Road at Hinterland Region

a) Review existing traffic volume area (intersection of four non signal) can meet and have a level of service B but for $\mathrm{HV}$ vehicles heading towards Situbondo must pass through the city because the roads are too narrow and can not meet the needs.

b) With the increasing number of vehicles in 2016, the level of service drops to $\mathrm{C}$ but still decent.

c) By widening the ring road towards Situbondo according to standard (7 m), it can be an alternative to the $\mathrm{HV}$ vehicle towards Situbondo.

\section{Recommendations}

In accordance with the secondary data, field observations, and processeddata, then we give some suggestions which is also an alternative solution of the above problems:

1. Alternatives to address the needs of ship mooring space in 2016 is to change the way aft mooring of vessels become dilated.

2. To meet the needs of car parking spaces in the port 2016 can capitalize on the breakwater area for motorcycles and cars as well as parking spaces that have been there before can be used for truck and pickup.

3. In accordance with the rules of urban traffic that HV vehicles are prohibited from passing on city streets, then to widen the ring road towards Situbondo who has been there can be a solution.

\section{References}

[1]. Morlok, Edward K. Pengantar Teknik dan Perencanaan Transportasi. Erlangga. Jakarta. 1988.

[2]. Nasution, H.M.N.MS.Tr. Manajemen Transportasi Ghalia Indonesia. Jakarta. Juni 1996.

[3]. Ofyar Z. Tamin, 2000, Perencanaan dan Permodelan Transportasi, PenerbitITB, Bandung.

[4]. Triatmodjo, Bambang. Pelabuhan. Beta Offset. Yogyakarta. Februari 1996.

[5]. Widyahartono, Bob. Manajemen Transportasi. Depdikbud Universitas Terbuka. Jakarta. 1986.

[6]. --------, 1996 Pedoman Teknis Penyelenggaraan Fasilitas Parkir. Jakarta: Direktorat Jenderal Perhubungan Darat, Departemen Perhubungan. 